\title{
Study on Ideological and Political Education of Linear Algebra Course
}

\author{
LIU Xian-bei ${ }^{1}$, LI li ${ }^{2}$
}

${ }^{1,2}$ School of statistics and Applied Mathematics, Anhui University of Finance and Economics, Anhui Bengbu 2003

\begin{tabular}{ll}
\hline ARTICLE INFO & ABSTRACT \\
\hline Publication Online: & To implement the ideological and political teaching concept of curriculum is a key measure to \\
& establish morality and cultivate talents in the new era, and also a basic requirement of colleges and \\
& universities' original mission of "educating talents for the Party and the country". University \\
& mathematics, as a basic subject universally offered in colleges and universities, has advantages in the \\
& course of ideological and political teaching, but also has obvious shortcomings. Linear algebra is a \\
& compulsory basic course for science and engineering majors, aiming at cultivating students' logical \\
& training and abstract thinking ability. This article mainly to the "Linear Algebra" teaching as an \\
& example, the first to study the Linear Algebra course ideological education and the advantages of the \\
& ideological education into the difficulty in the course, and put forward the linear algebra course \\
& ideological education the implementation of the specific methods: update teaching ideas, strengthen \\
& the teacher training, teaching methods and build a rich curriculum ideological system of the \\
implementation of the path.
\end{tabular}

KEYWORDS: Curriculum ideology and politics; Linear algebra; Teaching strategy

\section{INTRODUCTION}

Moral education is the first task of education, all courses have the function of educating people, all teachers are responsible for the important mission of ideological and political education, so all courses should implement ideological and political education[1]. Curriculum ideological and political education is to dig deeply and use the ideological and political education elements in various courses and teaching methods, effectively guide teachers to play the main role of curriculum and people, effectively put ideological and political education through the whole process of teaching practice, and realize the collaborative education of various courses. It is the main responsibility and mission of university education to integrate the ideological and political education idea into university mathematics teaching[2].

\section{DISCUSSION}

College mathematics courses mainly include "Advanced Mathematics", "Calculus", "Linear Algebra", "Probability theory and Statistics" and other courses. Generally speaking, most college students will learn these courses in the first two years of college, which can be said to be the public basic courses of college[3]. Mathematics is a basic subject generally opened in colleges and universities. Its research object is spatial form and quantitative relationship, mainly through rigorous logical thinking to reveal objective universal natural laws. It can be said that mathematics is the "method" science of other sciences. As a branch of university mathematics, Linear Algebra mainly studies finite dimensional linear equations, linear transformation, vector and vector space[4]. As a compulsory basic course for science and engineering majors in colleges and universities, it aims to guide students to solve practical problems with logical thinking and mode of linear algebra. Taking Linear Algebra as an example, we will discuss how to carry out ideological and political education of this course from three aspects.

2.1. Advantages of ideological and political education in linear algebra teaching

a. Students attach great importance to it

"Linear Algebra" course is set up the mathematics basic course in many colleges and universities, its teaching aim is to help students grasp the applied science that is commonly used in matrix, linear equations and quadratic form and related basic theory knowledge, intuitive and cultivate students' space imagination ability, abstract thinking and logical reasoning ability, and by utilizing the method of linear algebra 'ability to analyze and solve practical problems, At the same time, it is also the required content for most students to take the postgraduate entrance examination. Based on the above characteristics of Linear Algebra, many college students attach great importance to learning the knowledge of this course. Therefore, it is more meaningful for teachers of Linear Algebra to carry out ideological and political education through this course. 


\section{b. A large number of subjects}

The theory of linear algebra not only permeates into many branches of mathematics, but also has a wide range of applications in science and technology, agricultural medicine, economics and management and other disciplines. Therefore, it has become a public course in many colleges and universities, and some schools even list it as a basic course and a required course. In Anhui University of Finance and Economics, for example, $97 \%$ of students have offered linear Algebra. Therefore, if the teacher of Linear Algebra can integrate the ideological and political teaching idea into the whole teaching process and do a good job, the ideological and political education can be more efficient and better.

\section{c. The teaching target is young}

Values are a person's overall evaluation and view of the significance and importance of objective things around. Research shows that the formation of values has a lot to do with age, and they become mature and fixed with age. The essence of ideological and political teaching concept in curriculum is to integrate spiritual guidance of ideal and belief into the knowledge learning of "moistening things silently". Therefore, the earlier ideological and political education is introduced in curriculum, the more conducive to the formation of students' values. Taking Anhui University of Finance and Economics as an example, the course of Linear Algebra was basically opened in the second semester of freshman year or the first semester of sophomore year. The earlier ideological and political education is carried out, the better the effect will be. Therefore, the teacher of Linear Algebra should seize this opportunity and integrate the teaching concept of "curriculum ideological and political" into the process of college students' learning knowledge.

\subsection{Difficulties in the integration of curriculum ideology and politics with linear algebra teaching}

\section{a. Traditional teaching ideas are not suitable for development}

Think that the traditional teaching concept, "linear algebra" courses mainly research quantitative relation, the spatial relationship problems, focus on the objective law, beyond the ideological field, its teaching content contains basic concept, theory and method provides the tools and methods for scientific research, mainly focus on training students' mathematics quality and scientific thinking. Therefore, some people take it for granted that the thinking method contained in the teaching content of Linear Algebra has nothing to do with ideological and political standpoint, and it is difficult to integrate ideological and political education when studying the objective world with rational thinking. Therefore, the ideological and political teaching concept of the course is also difficult to effectively integrate with linear Algebra.

\section{b. There are deficiencies in the teaching materials used at present}

The content of Linear Algebra is abstract, theoretical and complicated. At present, the textbooks used by colleges and universities are generally recommended by the Ministry of Education or selected by themselves. Generally speaking, the contents of the textbooks are relatively simple, but there are no practical application examples, and there are no concepts or definitions to be elaborated from specific practical problems. Basically, definitions and theorems are given directly. This will make students unable to know or understand the definition, the necessity of theorems and principles. These deficiencies in the existing textbooks make the teaching content seem too abstract and students' interest in the course is not high.

\section{c. There are obvious shortcomings in teaching methods}

In the teaching process of Linear algebra, teachers generally adopt the teaching method of giving definitions and theorems first, and then giving examples for reasoning demonstration and explanation. Because of the course are very abstract concept, theory, the teaching method while to let the students to remember the definitions and theorems, but did not let the students grasp effectively to the source of the definition, the nature of the problem and reasoning process, so that the students one-sided think linear algebra is composed of definition, theorem, the lack of practicability, this greatly reduces the students' interest in learning. At the same time, students in the learning process, the understanding of the course content is not in place, their own learning motivation is insufficient, only satisfied with completing the classroom tasks assigned by the teacher. In addition, due to the limited teaching hours of Linear Algebra, teachers may not be able to introduce the origin of these knowledge in order to complete the class hours. Teachers' teaching methods and students' learning methods are relatively single and outdated, which further affects the teaching effect and the integration of ideological and political teaching ideas.

d. The ideological and political integration of the curriculum needs further exploration The idea of curriculum ideological and political teaching came into being relatively late. At present, various disciplines in colleges and universities are still groping for ways to integrate this teaching idea into their own disciplines. Especially in the process of "linear algebra" teaching, the classroom teaching of highly abstract and theoretical content, teaching teachers also lack of professional education teaching experience, the ideological content is still not form a system of teaching system, teaching design, teaching process easy to cause the separation of teaching content and ideological content. How to combine the characteristics of the subject, give full play to the ideological and political role of teachers, adopt a variety of teaching strategies, naturally integrate the inherent philosophy and value of teaching content, to achieve the goal of ideological and political education, is still the focus of linear algebra teaching.

2.3. Implementation methods of curriculum ideology and politics in linear algebra teaching It has become a general consensus in China's higher education circles to fully 


\section{"Study on Ideological and Political Education of Linear Algebra Course"}

implement the ideological and political teaching concept of curriculum. As a part of the university mathematics curriculum, the university mathematics curriculum also needs to learn from and share the existing curriculum research results, and more clearly integrate the ideological and political ideas into the teaching of the subject, so that the teaching process is full of ideological and political elements. To this end, the author believes that we should start from the following aspects:

\section{a. Timely update the teaching concept}

Han $\mathrm{Yu}$, an educator in the Tang Dynasty, once said, "Teachers, therefore, preach, receive lessons, and solve doubts." "Preaching" should be the primary task of teachers. The so-called "preaching" in the new era is to set up morality and cultivate people, which means to pay attention to the ideological and political education elements into the classroom of higher mathematics and guide students to establish correct values, outlook on life and world outlook. Under the guidance of curriculum ideological and political teaching concept, education needs to jump out of the mode of focusing only on educational skills reform, but flexibly use the subject thinking of ideological and political theory to deal with classroom teaching. Especially for those teachers who are engaged in teaching and researching with pure mathematical thinking, it is necessary to change their teaching ideas.

\section{b. Focus on strengthening teacher training}

Teachers are the concrete implementers and main implementers of the curriculum ideological and political education idea. Therefore, it is necessary to strengthen the ideological and political education and training of college mathematics teachers, strengthen the "four consciousness" and "four confidence", and cultivate their moral awareness and moral ability. We should change the idea that college mathematics teachers only pay attention to knowledge imparting and ignore value guidance, and insist on the ideological and political education idea throughout the whole process of education. In the process of strengthening the construction of teaching staff, we should pay attention to giving full play to the role of mentoring and teaching pioneers. We should pay attention to the use of various means, especially modern information technology means to strengthen the curriculum ideological and political teaching reform, let teachers actively through a variety of ways to lead the thought, ability training, knowledge imparting into the university mathematics curriculum.

\section{c. Focus on enriching teaching methods}

The reform and innovation of course ideological and political teaching methods is an important breakthrough point to strengthen and improve the construction of ideological and political theory courses in colleges and universities, as well as an important way to enhance the effectiveness of course ideological and political teaching and the overall quality of teaching. When choosing the teaching method of college mathematics, we should pay attention to the integration of ideological and political theory with the knowledge point of college mathematics. Should pay attention to make full use of all the useful resources around, such as multimedia teaching and blackboard teaching, online courses and face-to-face teaching complementary, in the imperceptibly so that students establish the correct world outlook, outlook on life and values. We should actively implement the concept of "student-centered", pay attention to the use of heuristic, discussion, guidance and inquiry teaching methods, let students deeply involved in the teaching process, let ideological and political elements throughout and permeate into the course teaching. According to the specific situation of students thinking and solving problems, guide students to deeply participate in teaching activities, and rely on modern information technology to assist teaching, after-class information feedback and data analysis statistics, continuous improvement of classroom teaching.

\section{d. Pay attention to the construction of curriculum} ideological and political system The main form of ideological and political education in the course is to integrate ideological and political education elements into the course teaching, influencing students' ideology and behavior imperceptively. At present, in the process of college mathematics teaching, teachers will intentionally or unintentionally integrate ideological and political education elements, such as the entrance education of the first class, the introduction of learning methods, etc., but the systematic curriculum ideological and political system has not been formed. Therefore, the university mathematics teaching teachers need to explore from the history of mathematics, Chinese mathematician story, mathematics and so on various aspects of knowledge, excavate ideological education elements, and then design a complete teaching cases, revision of teaching syllabus, curriculum education system and continue for a long time, in the university mathematics teaching into the ideological concept really implement.

\section{CONCLUSION}

It has become the consensus of Chinese higher education circles to fully implement curriculum ideology and politics. Integrating the ideological and political teaching concept into college curriculum teaching is conducive to bringing into play the collective wisdom of teachers, jointly promoting the improvement of ideological and political education level, and cultivating various talents suitable for the development of the new era. As university teachers, they should take the initiative to explore and practice, update their teaching concepts, dig out ideological and political elements contained in different professional fields, and infiltrate them into teaching practice, imparting correct world outlook, values and outlook on life to students, so as to truly combine ideological and political education with knowledge imparting. With the in-depth research of educational researchers on curriculum ideological and political theory and the practical exploration of university teachers, some courses have achieved good results in 
ideological and political education at present. However, the existing problems can not be ignored. We should make full use of the research methods and results of various disciplines, take teacher training, element discovery, teaching construction and method research as the starting point, and actively promote, truly realize "salt dissolve in water" and "spring breeze melts rain, moisten things silently".

\section{ACKNOWLEDGMENT}

This work was supported by the Education Research Project of the Education Department of Anhui Province (No.2020szsfkc0027)

\section{REFERENCES}

1. Wu Huizhuo. Exploration and Thinking of Ideological and Political Infiltration Courses in Advanced Mathematics Teaching[J]. College Mathematics, 2019,35(5):40-43.

2. Liu Shuqin. Curriculum Ideological and Political Cases in Advanced Mathematics[J]. Education Teaching Forum,2018.12(52):36-37.

3. Yang Wei, et al. Ideological and Political Exploration and Practice of University Mathematics Courses_- Taking the Linear Algebra Teaching of Xidian University as an Example[J].University Education,2020(3):11-14.

4. $\mathrm{Wu}$ Lu. Discussion on ideological and political advancement methods of large numbers mathematics course[J]. Journal of Higher Education, 2020 (4): 72-74. 